\title{
The quality of fermented goat milk produced by Pediococcus acidilactici BK01 on refrigerator temperature
}

\author{
SRI MELIA ${ }^{1, \bullet}$, INDRI JULIYARSI ${ }^{1}$, YULIANTI FITRI KURNIA ${ }^{1}$, YUDHA ENDRA PRATAMA ${ }^{2}$, \\ DHIVA REZZY PRATAMA ${ }^{2}$ \\ ${ }^{1}$ Faculty of Animal Science, Universitas Andalas. Jl. Univ. Andalas, Limau Manis, Padang 25171, West Sumatra, Indonesia. \\ Tel.: +62-751-71464, Fax.: +62-751-71464, `email: srimelia75@ansci.unand.ac.id \\ ${ }^{2}$ Animal Science Graduate Program, Universitas Andalas, J1. Univ. Andalas, Limau Manis, Padang 25171, West Sumatra, Indonesia
}

Manuscript received: 7 August 2020. Revision accepted: 11 September 2020.

\begin{abstract}
Melia S, Juliyarsi I, Kurnia YF, Pratama YE, Pratama DR. 2020. The quality of fermented goat milk produced by Pediococcus acidilactici BKO1 on refrigerator temperature. Biodiversitas 21: 4591-4596. This research aimed to determine the quality of chemical and microbiological milk of goats fermented with Pediococcus acidilactici BK01 with the storage time on refrigerator temperature. The method used is the experimental method of Completely Randomized Design with five times the treatment of goat milk fermentation at the refrigerator temperature is over $0,7,14,21$, and 28 days with four repetitions. The results showed long-lasting storage of real effect $(\mathrm{P}<0.05)$ on water content, $\mathrm{pH}$, titratable acid, total lactic acid bacteria, and total plate count, but no noticeable effect $(\mathrm{P}>0.05)$ on the protein levels and milk fat fermentation during the resulting storage. The value of moisture content during storage ranges between $85.88-84.92 \%, \mathrm{pH} 4.48-4.28,3.69-3.49 \%$ fat content, 3.53-3.58\% protein content, as well as the count of titratable acid ranging from $1.52-1.73 \%$. The whole colonies of lactic acid bacteria reached between $9.106 \log \mathrm{CFU} / \mathrm{mL}$ to $10.376 \log \mathrm{CFU} / \mathrm{mL}$, and the total plate count (TPC) value during storage experienced an increase from $2.653 \log \mathrm{CFU} / \mathrm{mL}$ to $4.012 \log \mathrm{CFU} / \mathrm{mL}$. Based on the results of the study can be concluded that the milk of goat fermentation with $P$. acidilactici BK01 can maintain quality until the retention period of 28 days with the viability of lactic acid bacteria that meet the category as probiotics and still liked by the consumer.
\end{abstract}

Keywords: Fermented milk, goat milk, lactic acid bacteria, Pediococcus acidilactici BK01

\section{INTRODUCTION}

Fermented milk is one of the products processed by livestock through the fermentation stage involving lactic acid bacteria. Raw materials that are widely used to make fermented milk are cow's milk, buffalo milk, sheep's milk, and goat's milk. In developing countries, goat's milk has been widely consumed because it has therapeutic benefits, high nutritional value, and as a source of probiotic microorganisms (Selvajeyanthi et al. 2019). In the processing of milk fermentation, it utilizes goat milk because goat milk has many benefits for health including: can increase the absorption of Fe, efficient for the healing of asthma and tuberculosis, containing proteins, vitamin A, vitamin B (riboflavin), enzymes, and high minerals, has a great potential as a probiotic carrier (Cahyanti 2011), due to the presence of potentially lactic acid bacteria as probiotics (Melia et al. 2018) and does not cause diarrhea. With this specialty owned by goat Milk, it makes the milk a suitable medium for the growth of the decay and pathogenic microorganisms. Therefore, some ways to extend the shelf life of goat milk can be done by processing goat's milk into fermented milk (Kurnia et al. 2014).

Fermentation of milk involves lactic acid bacteria, in which case it is used is Pediococcus acidilactici BK01. Excess strains of this $P$. acidilactici BK01 is a lactic acid bacteria. This is the result of isolation from Bekasam that has passed the selection as a probiotic bacteria (Melia et al.
2019). The selection of probiotic lactic acid bacteria among them can withstand the acidic condition of $\mathrm{pH} 2$ and resistant to bile salts $0.3 \%$ and has antimicrobial activity against pathogenic bacteria, namely Escherichia coli and Staphylococcus aureus (Melia et al. 2018; Melia et al. 2019). Lactic acid bacteria can inhibit the growth of pathogenic bacteria (Escherichia coli O157: H7 and Staphylococcus aureus ATCC25923) because of the presence of anti-bacterial compounds produced such as bacteriocin (Melia et al. 2017) and bacteriocin also inhibit Listeria monocytogenes (Pato et al. 2020).

Pediococcus acidilactici is a strain of lactic acid bacteria that is often used in the processing of dairy products because of its ability to produce acids and is beneficial for health. These bacteria have antimicrobial activity against several other bacteria and have the potential as probiotic (Holland et al. 2011). $P$. acidilactici produces a bacteriocin called Pediocin. Pediocin can inhibit the growth of positive gram bacteria and is also useful in inhibiting gram negative bacteria (Delves-Broughton 2012) and Pediocin PA-1, is a peptide that is an antimicrobial and is used as a bio preservative alternative in the food industry (Yusuf 2018). Pediocin, including a type of thermostabile protein, is active in preventing food spoilage and inhibiting pathogenic microorganisms such as L. monocytogenes, Enterococcus faecalis, S. aureus, and Clostridium perfringens (Gálvez et al. 2014; Juneja et al. 2012). 
The purpose of this research is to measure the chemical quality and microbiology of fermented milk made from the starter Pediococcus acidilactici BK01 during storage at refrigerator temperature.

\section{MATERIALS AND METHODS}

Fermented milk was made using the milk of the Peranakan Etawa and the starter of P. acidilactici BK01 as much as $5 \%$. The study used a Completely Randomized Design of 5 treatment of storage fermented goat milk, i.e., $0,7,14,21$, and 28 days with four repetitions at refrigerator temperature $\left(4^{\circ} \mathrm{C}\right)$.

\section{Fermented milk production}

Goat milk was pasteurized at a temperature of $65-67^{\circ} \mathrm{C}$ for 30 minutes, then the milk temperature up to $37^{\circ} \mathrm{C}$ (Donkor et al. 2006). Starter P. acidilactici BK01 added as much as $5 \%$, next incubated for 12 hours at $37^{\circ} \mathrm{C}$ temperature. Fermented milk of $P$. acidilactici BK01 was stored according to the treatment of $0,7,14,21$, and 28 days (modification of Melia et al. 2019).

\section{Determination of chemical parameters}

The determination of chemical parameters from fermented goat milk was moisture content, proteins, fats, Titratable Acid, and $\mathrm{pH}$.

\section{Moisture content}

Moisture content was measured by the drying-oven method (AOAC 2005). As much as 2 grams of fermented goat milk powder samples were prepared and put into a porcelain cup, which had measured its empty weight with an analytical balance, then each sample and cup was put into the oven and dried at $105^{\circ} \mathrm{C}$ for 4 hours. After it reached 4 hours drying oven, the sample was removed from the oven. Next, it was put in a desiccator for 15 minutes and weighed with an analytical balance. The moisture content was determined by calculating the weight subtraction between the samples before and after drying, and then was divided by the sample's weight, and finally multiplying it with $100 \%$ (AOAC 2005).

\section{Protein content}

A sample of 0.5 gram was put into a Kjeldahl flask, then it was added with $10 \mathrm{ml}$ of concentrated $\mathrm{H}_{2} \mathrm{SO}_{4}$ and 0.5-gram selenium, then it was destructed until the color turned into a clear green then followed by distillation. The distillation results were then titrated using $0.1 \mathrm{~N} \mathrm{HCl}$ until the color changed into purple and determined the blank form. Protein levels were calculated using the formula as described in Chang and Zhang (2017).

\section{Fat content}

Samples were weighed $1.5 \mathrm{~g}$ in filter paper (as weight A) and wrapped. The wrapped sample was dried in an oven at $105^{\circ} \mathrm{C}$ for 4 hours then weighed with analytical balance (as weight B). The sample was put into a fat flask and extracted by using ether solvent for 6 hours. After that, the sample was dried in an oven at $105^{\circ} \mathrm{C}$ for 1 hour, and it was weighed with analytical balance (as weight $\mathrm{C}$ ). The percentage of total fat content was determined by calculating the difference weight between dried and extracted dried samples. Then it was divided by the sample weight (AOAC 2005).

\section{Testing of $\mathrm{pH}$ and titratable acid}

$\mathrm{pH}$ testing using HANNA Romania the calibrated $\mathrm{pH}$ meter with a buffer of $\mathrm{pH} 4$ and $\mathrm{pH} 7$ (AOAC 2012). The titratable acid was measured by mixing fermented milk with $10 \mathrm{~mL}$ of aquadest, and it is calculated with $0.1 \mathrm{~N}$ $\mathrm{NaOH}$ using phenolphthalein indicator until it showed pink (Parmar 2003).

\section{Calculation of total plate count and total lactic acid bacteria}

The estimate of Total Plate Count (TPC) Paseephol and Sherkat (2009) and Total lactic acid bacteria and measured based on Harley and Presscot (2002).

\section{Sensory evaluation}

All fermented milk samples stored for $0,7,14,21$, and 28 days were evaluated for taste, aroma, and texture preferences by 25 staff members of the Animal Science Department. A five-point hedonic scale was utilized in this study $(1=$ dislike extremely; 2 = dislike slightly; $3=$ neither like nor dislike; $4=$ like slightly; $5=$ like extremely).

\section{Statistical analysis}

All the data obtained were analyzed statistically using experimental design, five treatments, and four repetitions. Data that has significant influence $(\mathrm{P}<0.05)$ was continued with the Duncan's Multiple Range Test using SPSS software statistic 19 .

\section{RESULTS AND DISCUSSION}

The research results showed that the longer the storage at the refrigerator temperature showed a significant effect $(\mathrm{P}<0.05)$ on water content, but showed no significant effect $(\mathrm{P}>0.05)$ to the protein and fat value in the resulting fermented goat milk.

\section{Moisture content}

Based on Table 1, It was known that there was a difference in the milk content of fermented goat after stored up to 28 days $(\mathrm{P}<0.05$ ). The results of water content analysis during storage decreased to $84.92 \%$ up to 7 days of storage and not significant after 14 days. This was suspected because goat milk ferments during storage absorbed water from its environment. The longer the storage water content will continue to increase, even though at the start of water content, storage can be decreased. The results of this study are in line with Melia et al. (2019), which was the moisture content of fermented goat milk containing Lactobacillus fermentum strains NCC2970 which range from $85 \%$ after storage for 15 days. 
This is supported by the statement of Herawati (2008), that changes in the water content of fermented milk can be influenced by the temperature and humidity of the room during storage and changed in water content in the product was a factor that is very influential to the decline in the quality of food products.

\section{Protein content}

Protein content of fermented goat milk (Table 1) during storage shows no significant effect $(\mathrm{P}>0.05)$ against the quality of the resulting protein. It was caused by the storage of fermented milk of $P$. acidilactici BK01, which was done at the refrigerator temperature until the storage of the 28th day has not influenced the resulting protein levels because it has not shown the sign will expire. From Table 1, it can be seen as protein levels fermented milk until the storage of 28 days still meet the quality standard of Indonesian National Standard 2981:2009 fermented milk, i.e., a minimum of $2.7 \%$. These protein levels are lower than Melia et al. (2019), which is about 4\%. This is likely due to the source of milk from different farms and the difference in the type of feed given, but the same as research with Güneş Bayır et al. (2019), which reported that the protein content of yogurt with the addition of cinnamon was $3.54 \%$.

\section{Fat content}

Fat is a component of milk that can provide higher energy than both protein and carbohydrates. Based on the results of the research known the highest fat content found in the 0-day storage was $3.69 \%$, and the lowest on the 28th day of storage was $3.49 \%$, but statistically showed a difference that was not significant $(\mathrm{P}>0.05)$. This was in line with the protein results gained that up to 28 days of storage have not given a noticeable effect on the resulting fat levels. This fat content is almost the same as the fat content of yogurt with the addition of cinnamon, 3.2-3.3\% (Güneş Bayır et al. 2019). If compared with the level of fat according to the quality standard fermented milk prescribed Indonesian National Standard 2981:2009, that was at least $3 \%$, then the milk of fermented goat $P$. acidilactici BK01 produced was worth consuming.

\section{pH}

The result of the analysis $\mathrm{pH}$ of fermented goat milk indicated a significant effect $(\mathrm{P}<0.05)$ between the duration of storage at the refrigerator temperature (Figure 1.). The longer the storage time was done, the $\mathrm{pH}$ value was decreasing. The decrease in the $\mathrm{pH}$ value was due to the activity of lactic acid bacteria derived from the starter $P$. acidilactici BK01 used in the manufacture of fermented goat milk. This bacteria will ferment lactose and will produce lactic acid, resulting in a decrease in $\mathrm{pH}$. It is by the opinions of Costa et al. (2016) that lactic acid bacteria ferment lactose into glucose and galactose, then the glucose was converted into lactic acid.

Also, a decrease in the $\mathrm{pH}$ of fermented goat milk during storage as the total acid increase of fermented milk was produced. The higher the whole level of fermented milk acid than the lower the $\mathrm{pH}$, as seen in this research.
According to Usmiati et al. (2011), the $\mathrm{pH}$ value of fermented milk will further decrease with the length of storage in cold temperatures. It was added by Melia et al. (2019) that the old storage of fermented milk using the starter Lactobacillus fermentum NCC2970 at a temperature of $4^{\circ} \mathrm{C}$ able to lower the $\mathrm{pH}$ value.

The $\mathrm{pH}$ value obtained in this study ranged from $4.28-$ 4.48. The results of this research were not much different from the Melia et al. (2019) research, where the $\mathrm{pH}$ of fermented milk is ranging from 4.0-4.9 so that it can be concluded that the $\mathrm{pH}$ value of milk fermented goat milk $P$. acidilactici BK01 which was stored at the temperature of the refrigerator until the storage of the 28th day, still able to maintain its quality. Abdel-Hamid et al. (2018), the $\mathrm{pH}$ value of fermented milk made from Lb. casei ATCC 393 decreased during storage at cold temperatures of 4.69 to 4.04 for 28 days. Furthermore, Bosnea et al. (2017) reported that Lb. casei ATCC 393 also decreased after 60 days of storage ( $\mathrm{pH} 4.27$ to 4.03). This is caused by the ability of $L b$. casei ATCC 393 produces organic acids during storage (Terpou et al. 2017).

\section{Titratable acid (TTA)}

The result of titratable acid of fermented goat milk indicated a significant effect $(\mathrm{P}<0.05)$ (Figure 2.) showed the more extended the fermented goat milk product was stored, and then the total lactic acid was increasing as the $\mathrm{pH}$ decrease occurred. A low $\mathrm{pH}$ would be a suitable environment for $P$. acidilactici BK01 (which is a homofermentative type bacteria) to grow and produce metabolites of lactic acid. It was by the opinions of Mal (2013) and Magalhaes et al. (2011) stating that the length of storage will affect the total lactic acid and generally, lactic acid bacteria can be distinguished into two groups, namely homofermentative and heterofermentative, where a homofermentative group of fermented glucose produces lactic acid as the only product, like Pediococcus and some Lactobacillus.

Based on the results of the research of fermented goat milk Paediococcus acidilactici BK01 stored at refrigerator temperature has qualified the quality of fermented milk Indonesian National Standard 2981:2009. The value of TTA fermented milk obtained in the research ranged from $1.52 \%-1.73 \%$ for 28 days of the storage period. A decrease in $\mathrm{pH}$ causes the increase in titratable acid during storage, which lactic acid bacteria ferment lactose to produce lactic acid (Costa et al. 2016). The results of the study were almost identical to the Melia et al. Research. (2019) on the quality, viability, and anti-bacterial properties of the Lactobacillus fermentum NCC2970 in goat milk fermentation at a temperature of $4^{\circ} \mathrm{C}$ with a TTA rate of 0.80-1.52 during 15-day storage. Thus, the value of the results of this research has fulfilled the criteria as fermented milk. Abdel-Hamid et al. (2018) also reported that fermented milk is made from $L b$. casei 393, increased during storage for 21 days in cold temperatures. This is the same as the research of Sah, Vasiljevic, McKechnie), which uses Lb. casei 393 to produce probiotic yogurt. Dimitrellou et al. (2016) also explain the increase in titratable acid during storage for 28 days (0.7 to 0.9$)$ along with a decrease in $\mathrm{pH}$. 


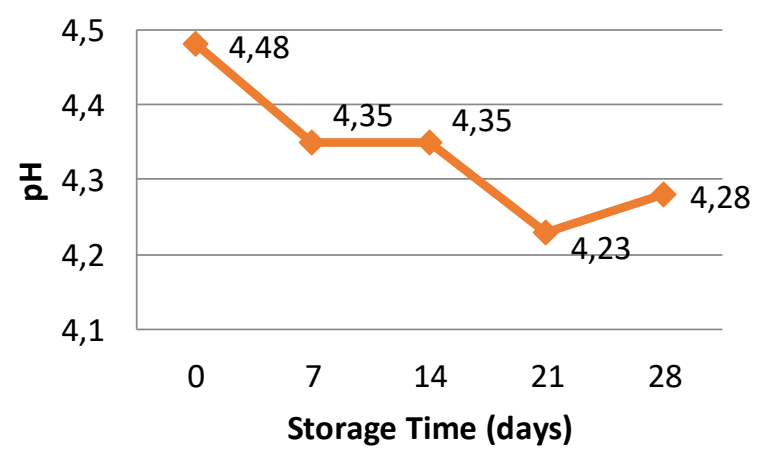

Figure 1. $\mathrm{pH}$ of fermented goat milk Pediococcus acidilactici BK01

Table 1. Chemical analysis of fermented goat milk of Pediococcus acidilactici BK01

\begin{tabular}{cccc}
\hline $\begin{array}{c}\text { Storage time } \\
\text { (days) }\end{array}$ & Water $(\%)$ & Protein $(\%)$ & Fat $(\%)$ \\
\hline 0 & $85.34^{\mathrm{ab}}$ & 3.53 & 3.69 \\
7 & $84.92^{\mathrm{b}}$ & 3.50 & 3.66 \\
14 & $85.88^{\mathrm{a}}$ & 3.55 & 3.53 \\
21 & $85.57^{\mathrm{ab}}$ & 3.56 & 3.57 \\
28 & $85.51^{\mathrm{ab}}$ & 3.58 & 3.49 \\
\hline
\end{tabular}

Note: Means within a column with different superscripts are significantly $(\mathrm{P}<0.05)$

Based on the data in Table 2, the duration of storage was significant $(\mathrm{P}<0.05)$, decreasing the total lactic acid bacteria of fermented goat milk. The longer it was stored, the total lactic acid bacteria will decrease. Many dead lactic acid bacteria caused this, due to the more extended storage conditions (28 days), resulting in reduced nutrient availability for $P$. acidilactici BK01 to produce lactic acid Same with Abdel-Hamid et al. (2018), fermented milk $L b$. casei ATCC 393, which is stored for up to 28 days in cold temperatures, has a number of lactic acid bacterial cells above $9 \log$ CFU g- ${ }^{1}$. Bosnea et al. (2017), Dimitrellou et al. (2016), and Sah et al. (2015) also reported a decrease in the number of bacterial cells after 60 days of storage at cold temperatures. Whereas Terpou et al. (2017) stated the decline in bacterial cells occurred after 30 days of storage.

The total decrease in Lactic Acid Bacteria in this study was also closely related to the decline in $\mathrm{pH}$ occurring. This was by the opinion of (Prasanna et al. 2013), the decrease in the number of lactic acid bacteria was closely associated with the reduction of $\mathrm{pH}$ products due to the accumulation of organic acids as a result of the metabolites of fermentation. $\mathrm{pH}$ decline will inhibit even stopping the growth of lactic acid bacteria itself.

The decrease in the amount of Lactic Acid Bacteria in this research was similar to the study by Melia et al. (2019). Where fermented milk was kept, then lactic acid bacteria decreased to $4.8 \times 10^{8} \mathrm{CFU} / \mathrm{mL}$. Further explained that it was caused by reduced lactose as a significant source of carbon by bacteria. Compared with Indonesian National Standard 2981:2009, the minimum amount of total Lactic Acid Bacteria in fermented milk is $10^{7} \mathrm{CFU} / \mathrm{mL}$.

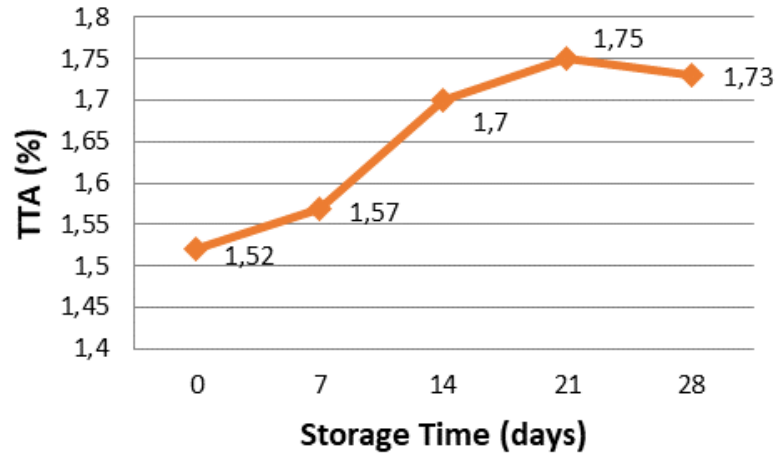

Figure 2. Titratable acid of fermented goat milk Pediococcus acidilactici $\mathrm{BK} 01$

Table 2. Total lactic acid bacteria and total plate count of fermented goat milk Pediococcus acidilactici BK01

\begin{tabular}{ccc}
\hline $\begin{array}{c}\text { Storage time } \\
\text { (days) }\end{array}$ & $\begin{array}{c}\text { LAB. } \\
(\text { Log CFU/mL) }\end{array}$ & $\begin{array}{c}\text { TPC } \\
(\log \text { CFU/mL) }\end{array}$ \\
\hline 0 & $10.376^{\mathrm{a}}$ & $2.653^{\mathrm{d}}$ \\
7 & $9.798^{\mathrm{bc}}$ & $3.891^{\mathrm{b}}$ \\
14 & $9.854^{\mathrm{b}}$ & $3.322^{\mathrm{d}}$ \\
21 & $9.833^{\mathrm{b}}$ & $3.633^{\mathrm{c}}$ \\
28 & $9.106^{\mathrm{c}}$ & $4.012^{\mathrm{a}}$ \\
\hline
\end{tabular}

Note: Means within a column with different superscripts are significantly $(\mathrm{P}<0.05)$

\section{Total plate count of fermented goat milk}

The number of aerobic bacterial colonies in fermented goat milk significantly $(\mathrm{P}<0.05)$ increasing with the more extended the storage period. The lowest amount of aerobic bacterial colonies in fermented goat milk was found on the 0 -day storage day of $2.653 \log \mathrm{CFU} / \mathrm{mL}$ and the highest on 28-day storage of $4.012 \log \mathrm{CFU} / \mathrm{mL}$. This condition was in line with the total lactic acid bacteria that the longer the storage was decreasing its number. It was closely related to the 4 phases experienced by lactic acid bacteria. The results of this research still meet the existing SNI. The maximum limit of its bacterial contamination, according to SNI, is $1 \mathrm{x}$ $10^{6} \mathrm{CFU} / \mathrm{mL}$.

\section{Sensory evaluation}

The sensory evaluation for $P$. acidilactici BK01 of fermented milk can be seen in Figure 3, which shows that the taste, aroma, and texture of fermented milk stored for 28 days did not show a significant effect $(\mathrm{P}>0.05)$. This means that storage time does not affect the taste, aroma, and texture of fermented milk. The level of consumer preference in terms of taste (3.59-3.70), flavor (3.70-3.80), and texture (3.70-3.84). The average result of the assessment by the panelists reached a score of 4 , namely like slightly. The same thing was shown by Ammar et al. (2019), bio-yogurt with the addition of honey, is still favored by consumers after being stored for 15 days. Furthermore, Huang et al. (2020) reported the fat free buffalo set of yogurt with the addition of $3 \%$ polydextrose stored for 21 days did not affect consumer acceptance. 


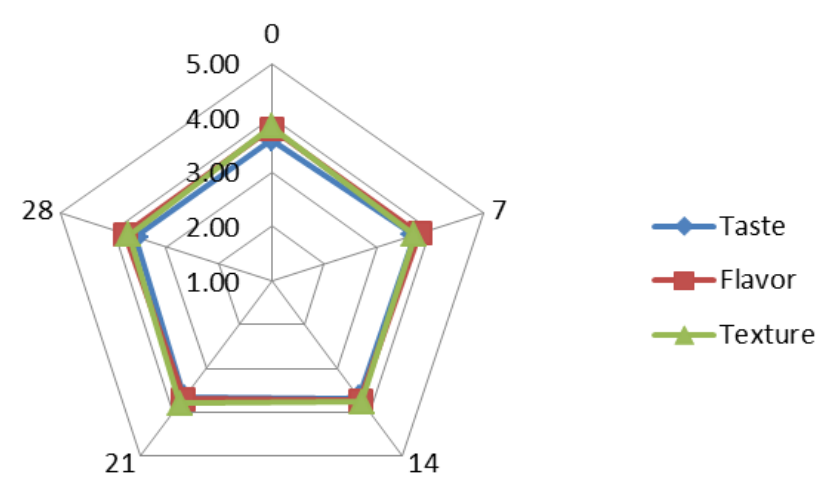

Figure 3. Consumer acceptability scores of fermented milk

In conclusion, extended storage in cold temperatures can affect the quality of milk of the fermented goat Pediococcus acidilactici BK01. The storage of goat milk fermentation for 28 days in cold temperatures can still maintain the number of lactic acid bacteria that meet the criteria of probiotics that are $9.106 \log \mathrm{CFU} / \mathrm{mL}$ with a titratable acid of $1.73 \%$ and $\mathrm{pH}$ of fermented milk goat reaches 4.28 , with a value of TPC $4.012 \log$ CFU/ ml, protein content $3.57 \%$, fat content $3.49 \%$, and moisture content $85.51 \%$ that still liked by the consumer.

\section{ACKNOWLEDGEMENTS}

This research was supported by research cluster publications to professors (Project No. T/8//UN.16.17/ PPT.01.03/Pangan-PTU-KRP2GB/LPPM/2020) LPPM Andalas University, Padang, Indonesia.

\section{REFERENCE}

Abdel-Hamid M, Romeih E, Gamba RR, Nagai E, Suzuki T, Koyanagi T, Enomoto T. 2018. The biological activity of fermented milk produced by Lactobacillus casei ATCC 393 during cold storage. Intl Dairy J 9: 1-8.

Ammar ET, Ismail MM, Khalil AEWE, Eid MZ. 2019. Impact of fortification with honey on some properties of bio-yoghurt. J Microbiol Biotechnol Food Sci 2019: 503-508.

AOAC. 2005. Official Methods of Analysis. Association of Official Analytical Chemists. Benjamin Franklin Station, Washington DC.

AOAC. 2012. Official Method of Analysis: Association of Analytical Chemists. 19th Edition. AOAC, Washington DC.

Bosnea LA, Kopsahelis N, Kokkali V, Terpou A, Kanellaki M. 2017. Production of a novel probiotic yogurt by incorporation of $L$. case enriched fresh apple pieces, dried raisins, and wheat grains. Food Bioprod Process 102: 62-71

Cahyanti AN. 2011.Viabilitas probiotik Lactobacillus casei pada yoghurt susu kambing selama penyimpanan beku. J Teknologi Pertanian 12: 176-180. [Indonesian]

Costa MP, da Silva Frasao B, da Costa Lima BRC, Rodrigues BL, Junior CAC. 2016. Simultaneous analysis of carbohydrates and organic acids by HPLC-DAD-RI for monitoring goat's milk yogurt fermentation. Talanta 152: 162-170.

Chang SKC, Zhang Y. 2017. Protein Analysis. In: Food Analysis. Springer, Cham. DOI: 10.1007/978-3-319-45776-536.
Delves-Broughton J. 2012. Natural antimicrobials as additives and ingredients for the preservation of foods and beverages. In: Baines D, Seal R (eds.). Natural Food Additives, Ingredients, and Flavourings. Woodhead Publishing, UK.

Dimitrellou D, Kandylis P, Petrović T, et al. 2016. Survival of spray-dried microencapsulated Lactobacillus casei ATCC 393 in simulated gastrointestinal conditions and fermented milk. LWT-Food Sci Technol 71: 169-174.

Donkor ON, Henriksson A, Vasiljevic T, Shah NP. 2006. Effect of acidification on the activity of probiotics in yoghurt during cold storage. Intl Dairy J 16 (10): 1181-1189.

Gálvez A, López RL, Pulido RP, Burgos MJG. 2014. Application of lactic acid bacteria and their bacteriocins for food biopreservation. Food Biopreservation, New York.

GüneşBayır A, Bilgin MG. 2019. The effect of cinnamon on microbiological, chemical, and sensory analyses of probiotic yoghurt. Bezmialem Sci 7 (4): 311-316.

Harley, Prescot. 2002. Laboratory Exercise in Microbiology. McGraw Hill Publisher, USA.

Herawati H. 2008. Penentuan umur simpan pada produk pangan. Jurnal Litbang Pertanian 27 (4): 124-130.

Holland R, Crow V, Curry B. 2011. Lactic acid bacteria Pediococcus spp. In: Fuquay JW (ed.). Encyclopedia of Dairy Sciences. Academic Press, USA

Huang L, Abdel-Hamid M, Romeih E, Zeng, Yang P, Walker G, Li L. 2020. Textural and organoleptic properties of fat-free buffalo yogurt as affected by polydextrose. Intl J Food Prop 23: 1-8.

Juneja VK, Dwivedi HP, Yan X. 2012. Novel natural food antimicrobials. Annu Rev Food Sci Technol 3: 381-403.

Kurnia YF, Yasni S, Nurtama B. 2014. Optimation formula of goat milk yoghurt and white oyster mushroom powder with mixture design methods. Pak J Nutr 13 (5): 296-302.

Mal R. 2013. Effect of Storage Duration in Refrigerator Temperature on $\mathrm{pH}$ Value, Viscosity, Total Lactic Acid and Profiles Protein Dissolved of Goat Milk Kefir. [Thesis]. Universitas Brawijaya, Malang. [Indonesian]

Magalhães KT, Pereira GVDM, Campos CR, Dragone G, Schwan RF. 2011. Brazilian kefir structure, microbial communities, and chemical composition. Braz J Microbiol 42: 693-702.

Melia S, Yuherman J, Purwati E. 2017. Characterization of the antimicrobial activity of lactic acid bacteria isolated from buffalo milk in West Sumatra (Indonesia) against Listeria monocytogenes. Pak J Nutr 16 (8): 645-650.

Melia S, Yuherman J, Purwati E. 2018. Selection of buffalo milk, lactic acid bacteria with probiotic potential. Asian J Pharm Clin Res 11: 186-189.

Melia S, Ferawati, Yuherman. 2018. Probiotic characterization of lactic acid bacteria isolated from raw milk (Buffalo, Cow, and Goat) from West Sumatra, Indonesia. Asian J Microbiol Biotechnol Environ Sci 20: 131-139.

Melia S, Ferawati, Zulkarnain I et al. 2019. Quality, viability, and antibacterial properties of Lactobacillus fermentum NCC2970 in probiotic fermented goat milk at $4^{\circ} \mathrm{C}$. Asian J Microbiol Biotechnol Environ Sci 21 (2): 237-242.

Melia S, Purwati E, Kurnia YF, et al. 2019. Antimicrobial potential of Pediococcus acidilactici BK01 from Bekasam, fermentation of sepatrawa fish (Tricopodus trichopterus) from Banyuasin, South Sumatra, Indonesia. Biodiversitas 20 (12): 3532-3538.

Parmar R. 2003. Incorporation of Acid Whey Powders in Probiotic Yoghurt. [Thesis]. South Dakota State University, USA.

Paseephol T, Sherkat F. 2009. Probiotic stability of yoghurts containing Jerusalem artichoke inulins during refrigerated storage. J Funct Foods 1: 311-318.

Pato U, Yusuf Y, Fitriani S, Jonnadi NN, Wahyuni MS, Feruni JA, Jaswir I. 2020. Inhibitory activity of crude bacteriocin produced by lactic acid bacteria isolated from dadih against Listeria monocytogenes. Biodiversitas 21: 1295-1302.

Prasanna PHP, Grandison AS, Charalampopoulos D. 2013. Microbiological, chemical and rheological properties of low fat set yoghurt produced with exopolysaccharide (EPS) producing Bifidobacterium strains. Food Res Intl 51: 15-22.

Selvajeyanthi S, Hemashenpagam N, Vinotha M. 2019. Potential probiotic analysis: indigenous lactic acid bacteria from freshly drawn goat milk. Intl J Sci Res Biol Sci 6: 65-72.

Sah BNP, Vasiljevic T, McKechnie S, Donkor ON. 2015. Effect of refrigerated storage on probiotic viability and the production and 
stability of antimutagenic and antioxidant peptides in yogurt supplemented with pineapple peel. J Dairy Sci 98: 5905-5916.

Usmiati S, Broto W, Setiyanto. 2011. Character of cow's milk curd using probiotic bacteria starter. Jurnal Ilmu Ternak dan Veteriner 16 (2): 140-152. [Indonesian]

Terpou A, Gialleli AI, Bekatorou A, Dimitrellou D, Ganatsios V, Barouni E, Kanellaki M. 2017. Sour milk production by wheat bran supported probiotic biocatalyst as starter culture. Food Bioprod Proc 101: 184192.

Yusuf M. 2018. Natural antimicrobial agents for food biopreservation. In: Grumezescu A, Holban M (eds.). Food Packaging and Preservation. Academic Press, USA. 